\title{
RECREATIONAL LANDS AS A COMPONENT OF HEALTH CARE: SOME ASPECTS OF LEGAL REGULATION
}

D0I: 10.36740/WLek202012226

\author{
Olena M. Batyhina', Bogdan V. Derevyanko ${ }^{2,3}$, Vitalii V. Kadala ${ }^{2}$ \\ 'POLTAVA LAW INSTITUTE OF YAROSLAV MUDRYI NATIONAL LAW UNIVERSITY, POLTAVA, UKRAINE \\ ${ }^{2}$ DONETSK LAW INSTITUTE OF THE MINISTRY OF INTERNAL AFFAIRS OF UKRAINE, KRYVYI RIH, UKRAINE \\ ${ }^{3}$ ACADEMICIAN F.H. BURCHAK SCIENTIFIC RESEARCH INSTITUTE OF PRIVATE LAW AND ENTREPRENEURSHIP OF THE NATIONAL ACADEMY \\ OF LEGAL SCIENCES OF UKRAINE, KYIV, UKRAINE
}

\begin{abstract}
The aim: The purpose of the study is to assess the impact of recreational lands on human health and determine the priority forms of their use and protection. Materials and methods: International acts, data of international organizations and findings of scientists have been examined and used in the study. The article also summarizes information from scientific journals and monographs from a medical and legal point of view on the basis of scientific methods. This article is based on dialectical, comparative, analytic, synthetic, and comprehensive research methods.

Conclusions: Recreational lands positively influence human health through a powerful effect of natural healing resources in combination with health-improving and therapeutic procedures on the body, which is becoming increasingly popular, and in some cases, it is the most effective treatment of all.

Recreational lands are an independent category of land with a special legal regime of use, characterized by a developed or undeveloped natural area containing natural resources for treatment, recovery, rehabilitation, and prevention of diseases, which are under the special protection of the state and territorial communities. Special protection of the state in today's conditions is extremely important because there has been a negative trend in Ukraine regarding raider attacks. The objects of such attacks are exclusively those companies that are competitive in the market, have achieved significant profits, and continue to develop their activities by creating new branches and introducing new technologies. In particular, attacks on the property of agricultural enterprises and business entities that carry out activities in the field of IT services have become frequent in recent years [1, p. 172]. The main target of attacks by raiders on agricultural enterprises is their land. Similarly, without state support and protection, recreational land can be the object of raider attacks.

The priority form of using recreational land is the placement of resorts and sanatoriums that provide recreational services. Recreational lands can also be used for health improvement in the "wellness" form or within the framework of health tourism.
\end{abstract}

KEY WORDS: human health, recovery, land

Wiad Lek. 2020;73(12 p. II):2860-2864

\section{INTRODUCTION}

The regulatory documents of the World Health Organization and the decisions of the European Court of Human Rights recognize the right to health to be a fundamental right. Ensuring the right to health and preserving the health of the population is carried out, inter alia, by using the beneficial and recreational properties of the land. The value of health improvement and treatment on recreational lands is determined by staying in natural conditions and the positive impact of various natural healing factors. Therefore, visiting ecologically clean places, recreational places, and carrying out medical procedures with the help of natural healing resources of the earth is a guarantee of good health.

The essence of the concept of recovery is reduced to the possibility of restoring the body's resources, improving working capacity, and productivity. British scientists from the University of East Anglia conducted more than 140 studies, which involved about 290 million people from 20 countries. It was found that outdoor recreation helped to reduce the risks of de- veloping type II diabetes mellitus, cardiovascular disease, high blood pressure and helps to avoid premature death [2]. That is why the health improvement on recreational lands using the natural healing properties of the earth requires research.

A number of international instruments recognize the need for the rational use of available natural resources to improve and maintain human health, in particular, the first principle of the 1992 Rio Declaration on Environment and Development notes that "caring for people is central to efforts to achieve sustainable development. They have the right to a healthy and fruitful life in harmony with nature" [3]. In turn, the World Health Organization defines that global health is being influenced by three trends: population aging, rapid unplanned urbanization, and globalization, all of which results in unhealthy environments and behaviors [4]. According to a report published by the World Health Organization, the polluted environment is a leading cause of death in the world [5]. WHO also identifies several other environmental causes and their relation to mortality, name- 
ly: land pollution, exposure to chemicals, climate change and ultraviolet radiation, etc. [6]. It follows that the issue of proper use, protection and enhancement of the healing, medicinal and health-improving properties of the earth is relevant and important for the preservation of human health.

A modern and developed state is called upon to take care of the life, health, safety and development of the population as the fundamental intrinsic value of any society, and one of the important areas of modern state regulation is precisely the measures aimed at restoring and preserving the natural healing resources of the earth and creating conditions for maintaining and improving health.

\section{THE AIM}

To study the impact of recreational lands on human health, as well as to determine the priority forms of their use and protection.

\section{MATERIALS AND METHODS}

International acts, data of international organizations and findings of scientists have been examined and used in the study. The article also summarizes information from scientific journals and monographs from a medical and legal point of view with scientific methods. This article is based on dialectical, comparative, analytic, synthetic, and comprehensive research methods.

\section{REVIEW AND DISCUSSION}

The WHO charter proclaims the principle that the enjoyment of the highest attainable standard of health is one of the fundamental rights of every human [7]. If we refer to the European Court of Human Rights, the right to health is defined in a comprehensive manner and includes, inter alia, the right to a favorable ecological environment, which affects the state of health. A number of ECHR decisions are devoted specifically to the violation of the right to life and health in connection with negative environmental factors, in particular the following decisions: the Case of Guerra and Others v. Italy, 19 February 1998, Hatton and Others v. the United Kingdom, 8 July 2003, Dubetska and Others v. Ukraine, 10 February 2011, Hrymkovska v. Ukraine, 21 July 2011, and Dzemyuk v. Ukraine, 4 September 2014, etc. The main problem of protecting the rights to a favorable ecological environment, which affects the state of health, is that the 1950 Convention for the Protection of Human Rights and Fundamental Freedoms does not contain an article that would directly protect the rights of everyone to an environment safe for life and health. Therefore, the analysis of the ECHR practice is carried out in a comprehensive manner in accordance with the provisions enshrined in various articles of the Convention. In fact, the ECHR recognizes the existence of a violation of environmental human rights only in the context of Article 8 of the Convention, which guarantees the right to respect for his private life.

Various factors can have a significant impact on human health $[8,9,10,11]$, among which a special place is occupied by the state of the environment in general and the state of lands in particular. It is customary to refer to recreational lands as lands that have natural recreational properties that are used or can be used for the prevention of diseases and the treatment of people. The definition shows that the impact of recreational land on human health is significant.

Characterizing the recreational lands as a component of health care, their main characteristics can be distinguished as follows:

1. Recreational lands have natural healing properties. Natural healing properties are the natural healing resources on the territory of this category of lands, such as mineral and thermal waters, medicinal mud and ozokerite, brine of estuaries and lakes, seawater, natural objects and complexes with climatic conditions favorable for treatment, suitable for use for the purpose of treatment, medical rehabilitation and disease prevention (Article 6 of the Law of Ukraine On Resorts dated October 05, 2000). According to Chapter 1 of the Law of Georgia on Tourism and Resorts No. 599 dated 6 March 1997 natural curative (health resort) resources are mineral waters, therapeutic mud, carst caves suitable for treatment, the sea, forests, healing climate and other natural resources, which are used for treatment, preventive care and rehabilitation [12].

Thus, water, balneological, agroclimatic resources, or even several resources, are located on recreational lands. It is important to emphasize that usually it is not the lands themselves that have healing properties, but other natural healing resources located on them. There are enough potential natural resources in the world to allow extensive use of such resources for health and wellness purposes. Therapeutic and recreational methods are traditionally subdivided into the following main ones: climatotherapy (treatment with the help of a favorable climate), balneotherapy (mineral waters); peloidotherapy (mud), and additional: thalassotherapy (sea water), aerotherapy (mountain air), speleotherapy (cave microclimate), phytotherapy (phytobath, phytocenoses microclimate, i.e. a combination of a certain set of plants) [13, p.138].

2. The healing and recreational properties of recreational lands are of natural origin and usually cannot be created (reproduced) artificially. Therefore, according to Principle 2 Report of the United Nations conference on the human environment (Stockholm, 5-16 June 1972), the natural resources of the earth, including the air, water, land, flora and fauna and especially representative samples of natural ecosystems, must be safeguarded for the benefit of present and future generations through careful planning or management, as appropriate [14]. According to the 1982 World Charter for Nature, man can alter nature and exhaust natural resources by his action or its consequences and, therefore, must fully recognize the urgency of maintaining the stability and quality of nature and of preserving natural resources [15]. The 1992 UN Convention on Biological Diversity establishes that parties to the convention should take appropriate measures to preserve biological diversity [16]. The European Commission also pays great attention to preserving natural resources and limiting the negative impact of their use for healing and recreational purposes [17]. In other words, it is necessary to talk about the 
special value and need for increased protection of natural healing resources located on recreational lands by states, considering their nature of origin and in many cases non-reproducibility.

3. The natural healing resources of recreational lands are used in accordance with the characteristics and condition of each organism because each person has his or her own unique and inimitable organism and therefore all the features must be taken into account. For example, mud baths cannot be used by everyone, since its properties can in some cases, on the contrary, worsen the state of human health because of some diseases, pathologies, which, as a result of using mud baths, can be aggravated.

Because the temperature of the mud can reach about 100 degrees Fahrenheit, water will be drained from the body and can cause dehydration. If you have sensitive skin, the warm mud may cause skin irritation. It is important to be monitored by a spa professional while taking a mud bath because staying in the bath too long can cause heatstroke, nausea and fainting [18].

Therefore, according to the European Social Charter, everyone has the right to benefit from any measures enabling him to enjoy the highest possible standard of health attainable [19].

4. In fact, the impact of recreational lands on human health is carried out first through their official recognition as resorts of state or local importance. After receiving a special legal status, such lands are specially protected by the state and one can count on the proper quality of the received health services offered by the resorts. For example, pursuant to the Law of Ukraine No. 2637-VIII dated December 05, 2018 "On declaring the natural territories of the Kuyalnik estuary of the Odesa region as a resort of state importance", the above territories and the unique natural healing resources of this area have acquired special protection from the state.

5. Recreational lands, after the official assignment them the corresponding legal status, receive priority over lands with similar legal regimes, since recreational lands have valuable health-improving properties. For example, the valuable natural resources of the Kuyalnik estuary of the Odesa region make it possible to treat and prevent a wide range of diseases, from injuries of the musculoskeletal system to diseases of the gastrointestinal tract [20]. There are also different types of excellent mineral and thermal waters in Hungary, each suitable for treating different health problems: containing alkaline, bromine, radon, sulphates and iron, or in some cases they can be muddy-calcareous, sulphuric or carbonated. Mineral and thermal waters are most commonly used to treat musculoskeletal disorders, but they are also hugely beneficial in curing dermatological conditions, gynaecological problems, sports injuries [21], which of course must be taken into account in the protection and use of these lands.

6. Legislation of different countries defines a different, in comparison with other categories of land, legal regime for granting, withdrawing, using, protecting and changing the designated purpose of recreational lands. For example, the relevant provisions of the Law of Georgia On Tourism and Resorts No. 599 dated March 6, 1997, the Land Code of the Republic of Tajikistan, the Land Code of Ukraine, and the Law of Ukraine "On Resorts" dated October 05, 2000, are devoted to the peculiarities of the legal regime of this category of land. In addition, the aforementioned regulatory legal acts establish separate restrictions on the use of land for recreational purposes as objects of civil turnover. Thus, Articles 83 and 84 of the Land Code of Ukraine indicate that land under recreational facilities that have special ecological, health-improving, scientific, aesthetic, and historical-cultural value cannot be transferred from state and communal property to private property unless otherwise provided by law. Article 89 of the Land Code of the Republic of Tajikistan establishes the legal regime of recreational lands, referring land plots with natural healing factors (mineral springs, healing mud deposits, climatic and other conditions) favorable for the organization of prevention and treatment to this category. The lands of resorts are subject to special protection. In order to protect natural healing factors, sanitary protection districts are established at all resorts. Within these districts, it is prohibited to provide land plots for use by those enterprises, institutions, organizations, which activities are incompatible with the protection of natural healing properties and favorable conditions for recreation of the population [22].

7. Facilities associated with the use of natural healing properties of recreational lands should be located on these lands. As indicated in the Appendix to the General Assembly Resolution of the World Charter of Nature No. $37 / 7$, humanity is a part of nature and life depends on the continuous functioning of natural systems that are a source of energy and nutrients [15]. Therefore, the emphasis should be placed on the healing and recreational properties of the land and the best option for using such lands is to place resorts, sanatoriums, and health centers. For example, given the existence of 1,500 thermal wells and more than 270 types of certified mineral and thermal water, Hungary has 98 certified resorts [21]. Thus, the use of recreational land as a means of production or an economic spatial basis should be of a secondary nature.

The Law of Ukraine "On Resorts" No. 2026-III dated October 05, 2000 determines that a resort is a developed natural territory on recreational land, has natural healing resources necessary for their operation, buildings and structures with infrastructure facilities, is used for the purpose of treatment, medical rehabilitation, disease prevention, and recreation. The above law identifies a category that is new for land legislation as a healing and recreational area - a natural area that has mineral and thermal waters, therapeutic mud, ozokerite, brine of estuaries and lakes, climatic and other natural conditions favorable for treatment, medical rehabilitation, and prevention of diseases. The concept of a resort in the legislation of Georgia is excellent, namely, the Law of Georgia On Tourism and Resorts reduces the concept of a resort only to a resort area where treatment and rehabilitation buildings or other infrastructure are located, without taking into account the presence or absence of natural healing resources of the 
land. The resort is a resort site where treatment or recovery buildings or other infrastructure are located. In the legislation of Georgia, the need for the availability of natural healing resources in the territories of resorts is defined through the concept of resort activities, where natural healing resources are already allocated as an integral part of resort activities [12].

Thus, sanatoriums are located in the resorts, provide treatment, prevention and rehabilitation services using natural healing resources, which makes it possible to argue about the location of such health facilities on recreational lands.

8. A separate form of use of recreational lands is tourism. There is no generally accepted and unambiguous concept of understanding the type of tourism, the purpose of which will be to use the healing properties of the earth's natural resources to improve human health. Different authors call it differently: health tourism [23], medical tourism [24], recreational tourism [25], [26], "wellness" tourism [27 p.50], etc. Thus, Atul D. Garud notes that relatively modern definitions "medical tourism", "wellness tourism" and "health tourism" refer to treatments that have been planned in advance to take place outside a patient's usual place of residence [28, p.318].

According to the Directorate-general for internal policies policy department for structural and cohesion policies transport and tourism research for the TRAN committee, medical tourism is a component of tourism activities and includes directly medical, health, and resort services. Herewith, medical tourism includes people who travel for the purpose of receiving treatment. Health tourism serves to maintain or improve personal health and well-being. Resort tourism focuses on healing, relaxing, or improving the body, which is preventive and/or curative in nature [29]. In turn, the Global Wellness Institute (GWI) defines wellness tourism as travel associated with the desire to support or increase personal well-being and believes that wellness tourism is not medical tourism, since the purpose of medical tourism is to travel to receive treatment for a diagnosed disease, malaise or a pathological condition. Within the framework of health tourism, a person is motivated by the desire for a healthy lifestyle, disease prevention, stress reduction, and bad lifestyle habits [30, pp. $9,11]$. Travel to receive treatment for a diagnosed disease, ailment, or condition, or to seek enhancement. Travel to maintain, manage, or improve health and wellbeing. Motivated by desire for lower cost of care, higher quality care, better access to care, and/or care not available at home. Motivated by desire for healthy living, disease prevention, stress reduction, management of poor lifestyle habits, and/ or authentic experiences. Activities are reactive to illnesses, medically necessary, invasive, and/or overseen by a doctor.

Recently, such a form of using the healing and health properties of lands as "wellness" has been developing all over the world. Wellness refers to the overall process of maintaining a healthy balance of the mind, body and spirit, which promotes good health and wellbeing. Multidimensional and holistic, wellness is a never-ending process of people becoming aware of and making lifestyle choices in order to enjoy a healthy and fulfilled life [31].

In our opinion, it is recreational tourism that better matches the essence and purpose of recreational lands since the emphasis is not on the possibility of obtaining certain medical services using specialized medical workers, but on the alternative procedures carried out in interaction with natural healing resources (sea coast, hot, warm and cold mineral springs, estuary mud deposits, forests, etc.), which are located on recreational land, for the sake of implementing a set of preventive measures to prevent the development of the disease or maintain the patient's condition. Along with the above forms, namely: the placement of sanatorium-resort institutions and the implementation of health tourism, we single out a separate form of land use for health purposes - "wellness".

\section{CONCLUSION}

Wellness is the key to good health. One of the main factors of healing and treatment is the use of the natural healing properties of the earth, it is becoming increasingly popular and, in some cases, something more effective simply does not exist. Recreational lands have a positive impact on human health through a combination of the effects of recreational and medical procedures with a powerful impact of the full range of natural healing resources on the human body.

Recreational lands are an independent category of lands with a special legal regime of use, characterized by a developed or undeveloped natural area containing natural resources for treatment, recovery, rehabilitation, and prevention of diseases, which are under the special protection of the state and territorial communities.

Recreational facilities (resorts and sanatoriums) that provide recreational services are located on recreational lands. Recreational lands can be used for health improvement within the framework of recreational tourism or in the form of "wellness".

The preservation of such lands should be ensured by increasing the efficiency of environmental policy, by identifying specific ways of their effective use.

\section{REFERENCES}

1. Bogdan Derevyanko, Vitaliy M. Pashkov, Olha A. Turkot, Nadiia V. Zahrisheva and Olena S. Bisiuk Addressing the issue of corporate raiding in Ukraine. Problems and Perspectives in Management, 2020.18(1), 171-180. doi:10.21511/ppm.18(1).2020.15.

2. lak vidpochynok na pryrodi vplyvaie na zdorovia: nespodivani fakty. [How outdoor recreation affects health: unexpected facts]. 11 yiulia 2018. Available from: https://health.24tv.ua/yak_vidpochinok_ na_prirodi_vplivaye_na_zdorovya_nespodivani_fakti_n997330 [reviewed 2020.08.20] (Ua).

3. Report of the United Nations Conference on Environment and Development. Rio de Janeiro. 3-14 June 1992. Available from: https:// bitly.su/APo0 [reviewed 2020.08.20].

4. WHO. Global recommendations on physical activity for health. Available from: https://apps.who.int/iris/bitstream/ handle/10665/44399/9789241599979_eng.pdf? sequence $=1$ [reviewed 2020.08.20]. 
5. WHO. Publichealth and the environment. Available from: https://www. who.int/gho/phe/en/ [reviewed 2020.08.20].

6. WHO. Quantifying environmental health impacts. Available from: https://www.who.int/quantifying_ehimpacts/news_events/en/ [reviewed 2020.08.20].

7. Constitution of the World Health Organization was adopted by the International Health Conference held in New York from 19 June to 22 July 1946, signed on 22 July 1946 by the representatives of 61 States. Available from: https://www.who.int/governance/eb/ who_constitution_en.pdf?ua=1 [reviewed 2020.08.20].

8. Pashkov V., Batyhina 0., Trotska M. Concept of waste and its impact on human health. Wiad. Lek. 2017; 5 :964-970.

9. Pashkov V., Batyhina 0., Leiba L. Ensuring right to organic food in public health system. Wiad. Lek. 2018; 1 : 226-229.

10. Gutorova N., Batyhina 0., Trotska M. Legal Protection of Public Health Through Control over Genetically Modified Food. Wiad. Lek. 2018; 2 : 366-370.

11. Derevyanko B., Soloviov 0., Batyhina 0. Mental health improvement and rehabilitation with in rural green tourism. Acta Balneologica. 2019; 4(158): 278-282.

12. On tourism and resorts: Law of Georgia. Entry into force 06.03.1997. Available from: https://matsne.gov.ge/en/document/ view/33370?publication=8 [reviewed 2020.08.20].

13. Ustymenko L.M. Istoryko-suspilni aspekty stanovlennia ta rozvytku likuvalno-0zdorovchoho turyzmu [Historical and social aspects of the formation and development of health tourism]. Pytannia kulturolohii. 2014; 30: 134-142. (Ua).

14. Report of the United Nations conference on the human environment. Stockholm. 5-16 june 1972. Available from: http://www.undocuments.net/aconf48-14r1.pdf [reviewed 2020.08.20].

15. The General Assembly. World Charter for Nature. 28.11.1982. Available from: https://sedac.ciesin.columbia.edu/entri/texts/world.charter.for. nature.1982.html [reviewed 2020.08.20].

16. United Nations. Convention on biological diversity.1992. Available from: https://www.cbd.int/doc/legal/cbd-en.pdf [reviewed 2020.08.20].

17. European Commission. Sustainable tourism. 2017. Available from: https://ec.europa.eu/growth/sectors/tourism/offer/sustainable_en [reviewed 2020.08.20].

18. Megan Smith. Side effects of mud bath therapy. 28 September. 2017. Available from: https://oureverydaylife.com/side-effects-of-mudbath-therapy-12177926.html [reviewed 2020.08.20].

19. European Social Charter (Revised). Strasbourg. 3.V.1996. Available from: https://rm.coe.int/168007cf93 [reviewed 2020.08.20]

20. Kuyalnik Estuary. Available from: https://bitly.su/Z1PRw [reviewed 2020.08.20].

21. Tourism and health tourism in Hungary. Available from: https:// wowhungary.com/en/experiences/healthtourism-13 [reviewed 2020.08.20].

22. Land Code of the Republic of Tajikistan. Entry into force: 03.12.1996. Available from: https://bitly.su/ZxSNy [reviewed 2020.08.20].

23. Smith M., Puczkó L. More than a special interest: defining and determining the demand for health tourism. Tourism recreation research. 2015; 40(2): 205-219.

24. Medical tourism association. A global platform for the health care ecosystem. Available from: https://www.medicaltourism.com/mta/ home [reviewed 2020.08.20].
25. Reznikova N., Ivashchenko 0., Voitovych 0. Pro spivvidnoshennia poniat likuvalnoho i ozdorovchoho turyzmu v konteksti otsinky potentsialu mizhnarodnoho rynku medychnykh posluh [The relation between the notions of health care tourism and wellness tourism in the context of assessment of the capacity of the international market of medical services]. Efektyvna ekonomika. 2018; 2. Available from: http://www.economy.nayka.com.ua/pdf/2_2018/14.pdf [reviewed 2020.08.20] (Ua).

26. Rutynskyi M., Petranivskyi V. Likuvalno-ozdorovchyi turyzm: aktualni tsili ta suchasni pidkhody do orhanizatsii. Visnyk Lvivskoho universytetu. Seriia mizhnarodni vidnosyny. [Medical and health tourism: current goals and modern approaches to the organization]. 2012; 29 (1):179189. Available from: https://tourlib.net/statti_ukr/rutynsky7.htm [reviewed 2020.08.20] (Ua).

27. Ustymenko L., Bulhakova N. RozvytokWellness-turyzmu ta yoho vplyv na transformatsiiu turystychnoi industrii Ukrainy. [Development of wellness tourism and its impact on transformation of the tourism industry of Ukraine]. Visnyk Kyivskoho natsionalnoho universytetu kultury i mystetstv. Seriia Turyzm. 2019; 2(1): 49-59. (Ua).

28. Atul D. Garud medical tourism and its impact on our healthcare. NAT'L MED. J. India. 2005; 18: 318-319.

29. Directorate-general for internal policies policy department for structural and cohesion policies transport and tourism research for TRAN. Committee - Health tourism in the EU: a general investigation. June 2017. Available from: https://bitly.su/Mz80 [reviewed 2020.08.20].

30. Global wellness institute. Global wellness tourism economy. November 2018. Available from: https://bitly.su/APoO [reviewed 2020.08.20].

31. Guide to understanding the concepts of wellness and daily tips to enhance your well-being. Emotional\&Mental Wellness. Available from: https://drprem.com/wellness/what-is-wellness-understandthe-concept-of-wellness-insight-by-dr-prem-jagyasi/ [reviewed 2020.08.20].

\section{ORCID and contributionship:}

Olena Batyhina: 0000-0002-7245-9369 B,D,F

Bogdan Derevyanko: 0000-0001-7408-8285 A, E, F

Vitaliy Kadala: 0000-0002-6868-9487 A, E, F

\section{Conflict of interest:}

The Authors declare no conflict of interest.

\section{CORRESPONDING AUTHOR \\ Olena Batyhina}

Poltava Law Institute of Yaroslav Mudryi

National Law University, Poltava, Ukraine

e-mail: elena0481@rambler.ru

Received: 24.08 .2020

Accepted: 27.11 .2020

A - Work concept and design, B - Data collection and analysis, C - Responsibility for statistical analysis, D -Writing the article, $\mathbf{E}$-Critical review, $\mathbf{F}$ - Final approval of the article 